Jonas Nahm*

\title{
Renewable futures and industrial legacies: Wind and solar sectors in China, Germany, and the United Statest
}

\begin{abstract}
This article develops an explanation for patterns of industrial specialization in emerging high-technology industries through a comparative analysis of wind and solar sectors in China, Germany, and the United States. Although governments have held similar industrial policy goals in the support of renewable energy industries, firms in all three economies have established distinct innovative capabilities in response to the policies of the state. This article shows that firms utilize both legacy institutions and engage in relational learning in global networks to carve out distinct niches in emerging industries. Based on an original dataset of more than 200 firm-level interviews, the article suggests that the rise of global value chains has widened the space for national diversity in industrial specialization. Firms no longer have to establish the full range of skills required to bring an idea from lab to market, but can specialize and collaborate with others. In this context, firms respond to industrial policy by incrementally building on existing industrial capabilities and by relying on familiar public resources and institutions, even in emerging industries. These findings point to the role of industrial legacies in shaping firms' positions in global value chains and show that firms are active agents in maintaining distinct industrial specializations and domestic institutions under conditions of globalization.
\end{abstract}

\section{Introduction}

Comparative political economists have long studied the effects of globalization on industrial organization. Literatures have documented how, in the 1990s, new

\footnotetext{
*Corresponding author: Jonas Nahm, School of Advanced International Studies, Johns Hopkins University, Washington, DC, e-mail: jnahm@jhu.edu

$\dagger$ This article is based on research supported by the U.S. Army Research Laboratory, the U.S. Army Research Office, and the Minerva Research Initiative under contract/grant number W911NF-15-10116. Versions of this article were presented at the SASE London Global Value Chains workshop, the Brown University Watson Institute WIP, and the UC Irvine China Forum. I thank all the participants and three anonymous reviewers for their constructive feedback.
} 
digital technologies suddenly allowed for the electronic transmission of digital design blueprints to far-away production locations. ${ }^{1}$ These technological changes presented new options for the geographical separation of innovation and production and facilitated the rise of global value chains. ${ }^{2}$ Other literatures have pointed to the role of financial markets in rewarding the reorganization of global industries and the decline of the vertically-integrated firm. ${ }^{3}$ Subsequent studies have examined the governance of global value chains and their impact on economic development and industrial upgrading. ${ }^{4}$

This scholarship has investigated how changes in the global economy have affected the geographical location and patterns of industrial specialization of existing industries-automobiles, textiles, electronics, among others. Through a comparative analysis of wind and solar photovoltaic (PV) sectors in China, Germany, and the United States, this article develops an explanation for patterns of industrial specialization in emerging industrial sectors. Barely three decades old, commercial wind and solar industries developed after the rise of global value chains and without the presence of incumbent firms and existing production structures common to established industries. The production of wind turbines and solar panels did not reach scale-economies until the early 2000s, after China's 2001 WTO accession unleashed a rapid shift of manufacturing capacity to Asia (see Figure 1). ${ }^{5}$

However, even in new and emerging industries, cross-national variation in industrial specialization persists. Instead of competing head-on, renewable energy firms in China, Germany, and the United States have specialized in distinct varieties of innovation, frequently playing complementary roles in the development of new technologies. For example, in the United States the vast majority of wind and solar firms are startups with skills in the invention of new technologies, but with far fewer capabilities in commercialization and production. In 2009, out of one hundred U.S. solar PV firms, at least seventy-three were startups working on next-generation solar technologies. ${ }^{6}$ By contrast, most German wind and solar firms are small and medium-size businesses that use their skills in customization and small-batch production of components and complex production equipment to compete in global markets. More than seventy German firms are offering

1 Baldwin and Clark (2000).

2 Berger (2005), Chapter 4; Powell (2009); Sturgeon (2002).

3 Chandler and Hikino (1997); Davis (2009).

4 Berger and Locke (2001); Breznitz (2007); Gereffi et al. (2005); Steinfeld (2004); Sturgeon et al. (2008).

5 Berger (2013), 40-41.

6 Knight (2011), 176. 


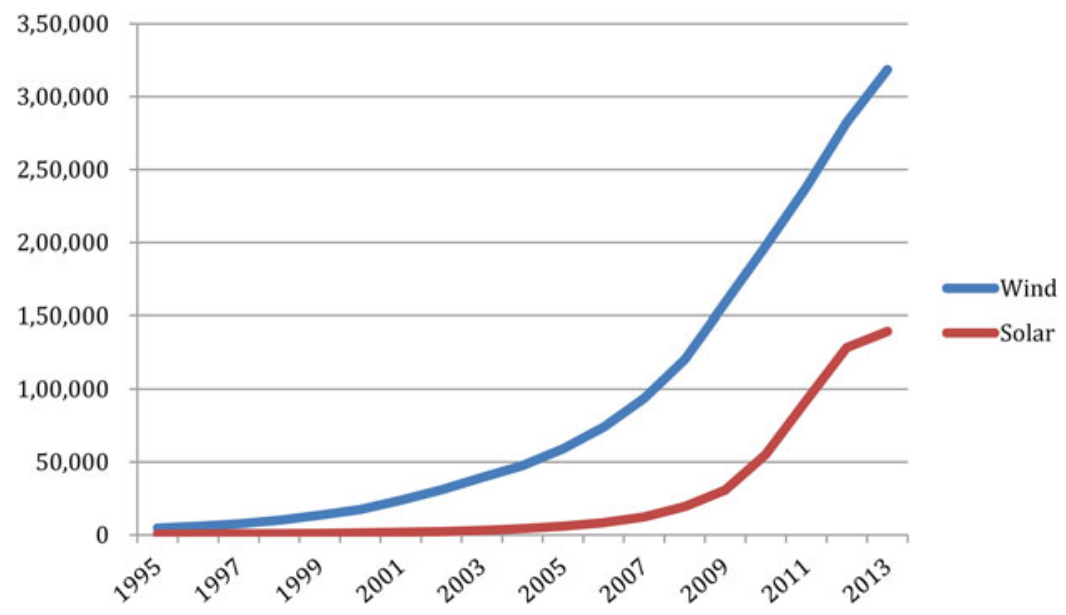

Figure 1: Global Production of Wind Turbines and Solar Panels in Megawatt (MW) Source: Data compiled by Earth Policy Institute 2015.

production equipment for the PV industry and more than 170 firms develop and produce components for the wind sector, compared to less than a dozen manufacturers of solar panels and wind turbines. ${ }^{7}$ In China-which is often portrayed as a recipient of technology transfers, rather than a contributor to innovation-large wind and solar manufacturers have focused on R\&D required for commercialization and scale-up of novel technologies. Among early entrants into wind and solar industries, Chinese firms were the first to bring wind and solar technologies to mass production as a result of such skills. ${ }^{8}$

These patterns of industrial specialization contrast sharply with the goals of policy-makers. Despite rapidly declining costs, renewable energy technologies are in many cases not yet competitive with conventional sources of energy, requiring subsidies or regulation to stimulate demand. ${ }^{9}$ Governments, of course, have justified such policy interventions and the related public investments in clean energy on environmental grounds. However, as political support for renewable energy has depended on the promise of tangible benefits for the broader economy, governments have also pursued industrial policy goals in their support for wind and solar technologies. ${ }^{10}$ Renewable energy policies, including

7 Arbeitsgemeinschaft Windenergie-Zulieferindustrie (2012); Germany Trade \& Invest (2010); Germany Trade \& Invest (2011b).

8 Nahm and Steinfeld (2014).

9 For an overview of national renewable energy strategies, see, for instance, REN21 (2012).

10 Zysman and Huberty (2013). 
$R \& D$ subsidies and policies to stimulate market demand, have sought to nurture vertically-integrated industries that can invent, commercialize, and produce competitive renewable energy technologies to generate such economic rewards domestically. ${ }^{11}$

What factors determine cross-national patterns of industrial specialization in such new and emerging industries? This article suggests that the globalization of production has widened the space for national diversity in industrial specialization and has allowed firms to replicate domestic industrial legacies for application in new sectors. Innovative capabilities that were once organized within large firms are now distributed across firms in global industries, including manufacturing firms in developing economies. In this context, firms no longer need to establish the full range of engineering skills required to bring an idea from lab to market, but can specialize and access complementary capabilities through collaboration with other specialized firms. Instead of converging on similar skills and competing with others head-on, wind and solar firms can contribute to global networks of innovators with niche capabilities.

In this context, firms respond to industrial policy by incrementally developing existing industrial capabilities, often through the repurposing of familiar public resources and domestic legacy institutions for application in new sectors. Globalization-by creating new opportunities for collaboration in global networks-has enabled firms to sustain these existing institutions as they seek out competitive niches in emerging sectors. The findings point to the importance of domestic institutions and relational learning in global networks in shaping firms' responses to industrial policy, moving beyond existing literatures that see industrial specialization primarily as the result of either sticky institutions at the domestic level or structural characteristics of global value chains.

The article begins with a brief review of the literature on industrial specialization under conditions of globalization. The empirical section that follows documents industrial policies for wind and solar sectors in China, Germany, and the United States. The article proceeds with a discussion of how firms responded to sectoral policy intervention by incrementally building on existing industrial capabilities through the use of legacy institutions. The final empirical section documents how collaboration in global networks enabled firms to engage in relational learning while maintaining such distinct national specializations over time. The article concludes with a discussion of the broader implications of these findings.

11 On protectionism in solar and wind industries, see Lewis (2014a, 2014b). 


\section{Globalization, Industrial Specialization, and the Global Division of Labor}

Increasing international competition, declining transport and communication costs, and new flows of goods and capital across national borders have long prompted scholars to question the ability of the state to shield national systems of social protection, domestic institutions, and national industrial practices from the pressures of the global economy. ${ }^{12}$ More than thirty years after these debates first emerged, it has become clear that increasing economic integration has not erased variation across national political economies. States have not converged in terms of the institutions that govern the domestic economy, nor in terms of patterns of industrial capabilities possessed by firms. ${ }^{13}$ Even where changes in the international economy have created pressures for reform, distinct national political economies have been preserved in the process of economic liberalization. ${ }^{14}$

National patterns of industrial specialization in wind and solar sectors, two emerging high-tech industries, are no exception to this trend. This is the case even though renewable energy policies in China, Germany, and the United States bear resemblance to one another and have followed similar industrial policy goals: governments in all three economies have employed subsidies for renewable energy markets and financial incentives for $R \& D$ with the goal of creating vertically-integrated domestic renewable energy sectors. ${ }^{15}$ Yet, wind and solar industries display remarkable cross-national variation in the types of industrial capabilities that firms possess in different economies. Firms in China, Germany, and the United States contribute distinct innovative capabilities to the development of global renewable energy sectors and show few signs of becoming more alike.

Existing literatures have investigated cross-national variation in firm capabilities from two different perspectives. A first group of studies, on global value chains (GVC), has attributed the industrial division of labor to linkages between firms that underpin the organization of the global economy and structure learning and knowledge transfers among firms. ${ }^{16}$ Broadly concerned with the ability of firms and nations to upgrade to high value-added activities, the GVC literature has

12 Berger (1996); Berger and Piore (1980); Ernst and Ravenhill (1999); Keohane and Milner (1996); Streeck (2009).

13 Breznitz (2007).

14 Thelen (2014).

15 REN21 (2015).

16 Lee (2010), 2990-93. 
examined barriers for firms from developing economies to emulate the capabilities of firms in advanced economies. ${ }^{17}$ Such scholarship initially differentiated among producer-driven and buyer-driven chains, each subject to different opportunities for upgrading. Highly hierarchical producer-driven chains, managed by verticallyintegrated enterprises that control the entire production system through direct ownership or subcontractors, offer few opportunities for learning or upgrading. In buyer-driven chains, lead firms source from a wide range of independent suppliers in global networks. With less control concentrated in the hands of individual firms and less hierarchical relationships among firms within the chain, lead firms in buyer-driven chains more frequently become sources of technology and knowledge for developing-economy firms. ${ }^{18}$

More fine-grained typologies of buyer-driven chains have subsequently focused on the ways in which power relationships between suppliers and lead firms, the technological complexity of interactions, and the properties of contemporary manufacturing technologies facilitate the flow of knowledge toward developing economies. ${ }^{19}$ The development of modular production technologies, in which complex design blueprints can be electronically transmitted to distant production locations, has lowered barriers to entry for firms in developing economies. However, studies have shown that this ability to geographically separate design and production activities in modular production networks has also offered fewer opportunities for learning and upgrading. ${ }^{20}$ By contrast, in emerging industries such as the wind and solar sectors examined in this article, the absence of incumbent firms and complex linkages between $R \& D$ and manufacturing should ease the flow of knowledge to developing-economy manufacturers seeking to emulate foreign R\&D skills.

A second group of studies, on the Varieties of Capitalism (VoC), has instead focused on institutions at the domestic level to explain industrial specialization in advanced economies. Hall and Soskice, among others, have argued that mutually-reinforcing institutional arrangements lead to stable national political economies, each corresponding to distinct types of production and innovation activities. In "coordinated market economies," such as Germany, institutions governing labor markets, financing, and employee participation in corporate governance create an environment best suited to industries based on incremental innovation. In "liberal market economies," such as the United States, domestic institutions

17 The evolution of this literature is reviewed, in detail, in Lee (2010).

18 Gereffi (1994).

19 Gereffi et al. (2005); Humphrey and Schmitz (2002, 2004).

20 Baldwin and Clark (2000); Berger (2005), Chapter 4; Feenstra (1998); Gereffi et al. (2005); Steinfeld (2004;) Sturgeon (2002). 
foster labor market flexibility, well-developed equity markets, and short-term profit horizons, which best suit firm strategies based on radical innovation. ${ }^{21}$

Political coalitions behind these institutional equilibria offer some protection of national political economies from the pressures of the global economy. However, more recent studies have investigated pathways for change within the VoC framework. ${ }^{22}$ Such work has highlighted how divergent patterns of coordination among domestic actors and the political coalitions among them lead to varied national responses to pressures for economic liberalization. While these changes may not entail convergence of national political economies and the industrial capabilities of firms within them, they nevertheless categorically pit global economic forces against legacy institutions and the political coalitions that support them. ${ }^{23}$ Economic competition and the growing reach of global finance has, in some places, triggered institutional reform. In other economies-in Germany in particular-such pressure has led to a new institutional dualism: an industrial core of legacy sectors invested in existing institutional arrangements that suit their production strategies, and a rapid shift of the remaining economic activity into spheres with fewer institutional constraints, such as the service sector. ${ }^{24}$

While emphasizing different drivers of cross-national patterns of industrial specialization, the GVC and VoC literatures share a joint focus on the effects of global economic integration on existing industrial sectors. Building on these contributions, this article seeks to develop an explanation for industrial specialization in emerging industries. In doing so, this research aims to capture both the dynamic development of emerging global industries and the role of domestic institutions in structuring firm responses to industrial policy. The findings presented here are based on an original firm-level dataset collected through 225 interviews with wind and solar firms, suppliers, and government officials in China, Germany, and the United States between 2009 and 2014 (see Table 1). Firms were contacted based on industry lists compiled from trade publications and industry associations. Semi-structured interviews with chief technology officers, R\&D teams, and production engineers asked about recent product development processes in each firm, as well as the public resources, domestic institutions, and collaborative relationships critical to carrying out this work. Interview data were subsequently triangulated with information from archival documents, Chinese government yearbooks, and financial filings.

21 Hall and Soskice (2001), 38-44.

22 Hall and Thelen (2009); Morgan and Whitley (2012); Streeck and Thelen (2005); Thelen (2014).

23 Höpner and Krempel (2004); Streeck (2009); Streeck and Mertens (2010).

24 Hassel (2014); Thelen (2014). 
Table 1: Interview Counts

\begin{tabular}{lcc}
\hline & \# of interviews & \# of firms interviewed \\
\hline Wind turbine manufacturers & 30 & 23 \\
Wind turbine component suppliers & 22 & 20 \\
Solar PV manufacturers & 35 & 29 \\
Solar PV component suppliers & 32 & 19 \\
Industry associations & 20 & $\mathrm{n} / \mathrm{a}$ \\
Government interviews & 49 & $\mathrm{n} / \mathrm{a}$ \\
Banks, VCs, investment firms & 37 & $\mathrm{n} / \mathrm{a}$ \\
Total & 225 & 91 \\
\hline
\end{tabular}

The data suggest a more recursive interaction of global and domestic factors in driving industrial specialization in emerging industries than existing literatures expect. This article argues that the ability of firms to craft distinct paths for participation in emerging industries is rooted in changes in the global economy itself: New options for specialization in global industries have allowed firms to pursue competitive strategies which build on, rather than compete with, existing industrial capabilities and the institutions to support them. The argument is in two parts. First, the findings presented here show that changes in the organization of production have dispersed innovative capabilities across global networks. Engineering skills that were once organized within vertically-integrated firms are now distributed across specialized firms in global chains that include manufacturers in developing economies. Since firms can access such capabilities through collaboration in global networks, they no longer need to establish in-house the full range of R\&D skills required to bring an idea from lab to market.

Second, as is detailed in the empirical sections that follow, these options for specialization have altered how firms respond to sectoral industrial policy. When firms are able to insert themselves into global networks of innovators with niche capabilities, they rarely establish in-house the full range of skills required to develop new technologies, but rather tend to specialize and collaborate with others. In this context, firms respond to industrial policy for emerging industries not through vertical integration, but through the incremental development of existing industrial capabilities and their application to new sectors. In doing so, firms rely on the appropriation and repurposing of familiar public resources and institutions at the domestic level, many of which were originally established for legacy, not emerging, sectors. The state, through traditional tools of industrial policy, is able to encourage firms to enter new industries. However, which technological specialization firms embark on in doing so depends on both the ability to 
enter collaborative relationships with other firms in global chains and the type of institutional support for firm-level learning accessible to firms domestically.

Literatures on the VoC have examined possibilities for institutional continuity in opposition to the global economy. In VoC scholarship, pathways for institutional change-reform, defection from existing institutions, and institutional dualismare responses to pressures emanating from international economic integration and the growing reach of global finance. By contrast, the data presented here suggest that the insertion into global chains can also enable firms in emerging industries to become part of political coalitions behind legacy institutions. Firms participate in such institutional arrangements not because they lack alternatives, but because these institutions provide resources for the specialized learning strategies they choose to pursue. Moreover, the empirical evidence presented here suggests that such learning does not entail emulation along a single trajectory of upgrading in global value chains. Even in cases in which interactions are complex, not hierarchically controlled by individual firms, and in which knowledge is tacit-circumstances which GVC literatures identify as promising for emulation and the flow of knowledge from advanced to developing economies-I show that firms follow distinct and complementary paths for upgrading that incrementally build on existing skills.

\section{The Creation of Wind and Solar Sectors in China, Germany, and the United States}

Renewable energy industries provide a valuable laboratory for an analysis of industrial specialization under conditions of globalization. First, as mentioned above, wind and solar sectors only fully developed after the globalization of production, offering insights into industrial specialization unaffected by incumbent firms and existing production structures specific to these industries. Second, they span vastly different technologies and supply chain structures. Wind turbines contain components assembled from more than eight thousand individual parts by more than one thousand different suppliers. Although some turbine components require the use of advanced materials and complex manufacturing processes, others, such wind turbine towers, rely on more traditional metalworking capabilities. ${ }^{25}$ The production of solar panels, by contrast, comprises far fewer actors and a much shorter supply chain that bears resemblance to the chemical manufacturing processes of the semiconductor industry. ${ }^{26}$ As such, a comparison of wind and solar

25 Dedrick and Kraemer (2011).

26 Shah and Greenblatt (2010). 
sectors offers a window into firm responses to industrial policy while isolating technology and supply chain differences as factors in industrial specialization.

In support of renewable energy sectors, policy-makers have attempted to marry environmental goals with economic objectives by using two sets of industrial policies. First, governments have encouraged innovation through R\&D subsidies to help domestic firms develop competitive wind and solar technologies. However, because in many parts of the world electricity generated from renewable sources is not yet competitive with conventional sources of energy, governments have also employed subsidies and energy market regulation to create market demand for wind and solar. Although differences exist in the implementation of such policies, the size of subsidies, and the conditions for government support, policy-makers in China, Germany, and the United States have pursued similar goals in the promotion of renewable energy sectors. In doing so, all three governments have combined elements of technology-push and demand-pull approaches to encourage the creation of vertically-integrated domestic renewable energy industries (see Table 2). ${ }^{27}$

The United States was the first and largest investor in renewable energy technologies. After the first 1970s oil shock, in 1974, the Energy Research and Development Administration (ERDA), predecessor to the Department of Energy (DOE), began administering $R \& D$ programs for renewable energy technologies. ${ }^{28}$ Such programs supported universities and national energy laboratories, but also sought to encourage private sector investments in wind and solar R\&D. The U.S. wind power research program allocated USD 380 million to aerospace and defense firms for the development of large wind turbine technologies between 1973 and 1988. ${ }^{29}$ Since the early 1990s, numerous programs administered by the National Renewable Energy Lab (NREL) have funded wind turbine R\&D in private firms. ${ }^{30}$ In the solar industry, the U.S. government has dispensed more than USD 3.3 billion of $R \& D$ support to the private sector. ${ }^{31}$

As in many other economies, public $R \& D$ funding has been combined with regulatory measures and subsidies to create market demand. In 1978, the U.S. federal government passed the Public Utilities Regulatory Policy Act (PURPA), which required utilities to purchase electricity from independent power generators. Beginning in the 1990s, the U.S. government began offering tax breaks for renewable energy installations. The 1992 Energy Policy Act included a

27 Nemet (2009).

28 Loferski (1993).

29 Righter (1996), 158.

30 Department of Energy (2006).

31 O'Connor et al. (2010), 3-11. 
Table 2: Select Industrial Policies for Wind and Solar Sectors

\begin{tabular}{|c|c|c|c|}
\hline & United States & Germany & China \\
\hline $\begin{array}{l}\text { Technology } \\
\text { Push }\end{array}$ & $\begin{array}{l}\text { 1973-1988 US Wind } \\
\text { Research Program } \\
\text { 1991-2000 PVMaT R\&D } \\
\text { Program } \\
\text { Since 1990s NREL R\&D } \\
\text { Grants } \\
2008 \text { American } \\
\text { Recovery \& } \\
\text { Reinvestment Act: } \\
\text { Loans } \\
\text { Since } 2009 \text { ARPE-E } \\
\text { Program }\end{array}$ & $\begin{array}{l}\text { Since } 1954 \text { Industrial } \\
\text { Collaborative } \\
\text { Research (ICR) } \\
\text { funding } \\
\text { Since } 1974 \text { Federal } \\
\text { Energy Research } \\
\text { Programs, renewed } \\
\text { six times }\end{array}$ & $\begin{array}{l}\text { Since } 1986 \text { R\&D } \\
\text { funding for applied } \\
\text { research through } \\
\text { "863 Program" } \\
2008 \text { "Indigenous } \\
\text { Innovation" Initiative } \\
2010 \text { “New Energy" } \\
\text { included under } \\
\text { Strategic Emerging } \\
\text { Industries }\end{array}$ \\
\hline Market Pull & $\begin{array}{l}1978 \text { Public Utility } \\
\text { Regulatory Policies } \\
\text { Act (PURPA) } \\
1992 \text { Production Tax } \\
\text { Credits (since then } \\
\text { renewed seven times) } \\
\text { Since } 1997 \text { Renewable } \\
\text { Portfolio Standards } \\
\text { (thirty states by 2012) }\end{array}$ & $\begin{array}{l}1990 \text { Electricity Feed- } \\
\text { In Law } \\
1998 \text { Renewable } \\
\text { Energy Sources Act } \\
\text { (EEG) } \\
2004 \text { EEG Renewed } \\
\text { (+ 2009, 2012, } \\
2014)\end{array}$ & $\begin{array}{l}2003 \text { Wind Power } \\
\text { Concession Program } \\
2006 \text { Renewable } \\
\text { Energy Law } \\
2007 \text { Feed-In Tariff: } \\
\text { Wind } \\
2009 \text { Feed-In Tariff: } \\
\text { Solar } \\
2009 \text { Golden Roofs } \\
\text { Initiative } \\
2009 \text { Golden Sun } \\
\text { Program }\end{array}$ \\
\hline
\end{tabular}

Production Tax Credit (PTC) for wind energy of 1.5 cents per kWh of installed wind power capacity. An investment-based tax credit was introduced for solar PV. ${ }^{32}$ Although tax credits for renewable energy became the subject of a political tugof-war in Congress, the PTC was renewed seven times since 1992, most recently in 2014. ${ }^{33}$ Federal tax credits were supplemented by state-level policies. By 2012, thirty states required electricity retailers to source a percentage of electricity from renewable sources through so-called Renewable Portfolio Standards (RPS), with some of the more ambitious states, such as California, setting renewable energy targets of 20 percent or more. ${ }^{34}$

The pattern of combining $R \& D$ funding for technology push and regulatory measures to create market demand was also followed in Germany and China. In

32 Laird and Stefes (2009), 2625.

33 Wiser et al. (2007), 79.

34 Shrimali et al. (2012), 33. 
the wake of the 1970s oil shocks, the German government increased its solar R\&D budget from USD 1.4 million in 1974 to USD 181 million in 1982. Funding for wind turbine technologies increased, from USD 7.9 million in 1977 to USD 53 million just four years later. ${ }^{35}$ Since 1977, a series of Federal Energy Research Programs (Energieforschungsprogramme) has subsidized $\mathrm{R} \& \mathrm{D}$ for designated energy technologies, including wind turbines and solar PV. The programs were renewed five times between 1981 and 2011, as their focus shifted from basic research in industrial laboratories and universities to bringing new technologies closer to commercialization and lowering production costs. Between 1990 and 2014, government R\&D funding for renewable energy technologies amounted to Euro 3.2 billion (USD 3.5 billion). ${ }^{36}$

Since the early 1990s, the German government has complemented support for renewable energy $R \& D$ with policies to stimulate market demand. In 1990, it passed Germany's first feed-in tariff, which required utilities to connect renewable energy generators to the grid and to buy their electricity at subsidized rates. The cost of these subsidies was spread among consumers through a surcharge on end-user electric bills. ${ }^{37}$ Such programs were extended in 1998, when the federal election was won by a center-left coalition that included the Green Party as a longterm champion of renewable energy. The new government passed the Renewable Energy Sources Act (Erneuerbare Energien Gesetz), which determined specific subsidies for each energy source, so that even costly technologies such as solar PV could be deployed. ${ }^{38}$ The law was amended in 2009, 2012, and 2014 to adjust subsidy levels to reflect the rapidly falling cost of solar PV panels and to encourage off-shore installations of wind turbines.

China's central government also took an early interest in renewable energy sectors, both to meet rapidly growing energy demand and as potential export industries. Beginning in the mid-1980s, the central government supported domestic $R \& D$ and technology transfers from foreign firms to catch up with the technological capabilities of firms in advanced economies. In 1986, China launched the National High Technology Research and Development Program, referred to as the 863 Program, which to this day provides competitive grants for applied research on renewable energy technologies. ${ }^{39}$ Between 2001 and 2005, the 863 Program dispensed RMB 20 billion (USD 3 billion) to research institutes and enterprises. ${ }^{40}$

\footnotetext{
35 IEA (2013).

36 Bundesministerium für Wirtschaft und Technologie (2011).

37 Lauber and Mez (2004), 602.

38 Bruns et al. (2011), 197.

39 OECD (2008), 386, 455-56.

40 Karplus (2007), 23-24.
} 
By the mid 2000s, seeking to reduce China's dependence on foreign technologies, the central government declared the pursuit of "indigenous innovation" (zizhu chuangxin) a national policy priority. The Medium- and Long-term Strategic Plan for the Development of Science and Technology (MLP) placed indigenous innovation at the core of China's developmental strategy, and selected a range of industrial sectors and research areas for special treatment, energy among them. ${ }^{41}$ Beijing increased R\&D funding to USD 17.8 billion in $2008 .{ }^{42}$ In 2010, as part of the renewed focus on indigenous innovation, renewable energy technologies were included in a list of seven "Strategic Emerging Industries" (zhanluexing xinxing chanye), which were to receive additional support from all levels of government. ${ }^{43}$

Just like the United States and Germany, China combined technology push with policies to create market demand. Beginning in 2003, China's Wind Power Concession Program provided subsidies for large-scale wind turbine installations through a government-run, tender-based bidding system. ${ }^{44}$ In 2006 , China's first Renewable Energy Law provided a framework for introducing feed-in-laws similar to those in effect in Germany. The Medium- and Long-Term Plan for Renewable Energy Development, issued in 2007, mandated that 15 percent of energy demand must be met from renewable sources by $2020 .{ }^{45}$ By 2009 , the central government had established China's first national feed-in-tariff for wind energy. ${ }^{46}$ At the same time, a first nation-wide feed-in-tariff for solar energy created a small but growing domestic market for solar PV, with additional subsidy programs available to support both residential customers and developers of utility-scale solar installations. Subsequent adjustments to the national feed-in tariffs further increased domestic markets for solar energy. ${ }^{47}$

Although differences in scale and timing of industrial policies for renewable energy sectors exist across China, Germany, and the United States, the broad policy tools employed by governments in each economy have been remarkably similar in content and goals. By combining public R\&D funding with regulatory policies to increase market demand, governments in each location have sought to establish domestic industries that could invent, commercialize, and produce green energy technologies.

\footnotetext{
41 State Council (2006).

42 UNESCO (2010), 389-390.

43 State Council (2010); U.S.-China Business Council (2013).

44 Ru et al. (2012), 65.

45 Lewis (2013), 53.

46 Earth Policy Institute (2015).

47 Zhang et al. (2014).
} 


\subsection{Varieties of Innovation in Wind and Solar Sectors}

Beginning in the early 2000s, the regulatory requirements for power utilities and subsidies for renewable energy markets created rapidly growing global demand for wind turbines and solar panels. Global installations for solar panels soared from $319 \mathrm{MW}$ in 2001 to 37,561 MW in 2013; over the same period, global wind turbine installations increased from 6,500 MW to 35,512 MW. China, Germany, and the United States made up a sizable share of these markets. Together, the three economies accounted for 55 percent of wind turbine markets and 50 percent of solar PV markets between 2001 and 2013. ${ }^{48}$ Such burgeoning global markets provided incentives for firms to enter renewable energy sectors and China, Germany, and the United States saw rapid growth of domestic wind and solar industries. Temporally, modern wind and solar sectors emerged virtually simultaneously in China, Germany, and the United States. Yet, geographically, firms in each location established distinct industry structures and national patterns of technological specialization despite similar industrial policies (Tables 3 and 4). This division of labor has remained remarkably stable over time.

In the United States, wind and solar industries were predominately populated by startup firms with capabilities in the invention of new technologies. A number of multinational energy and defense firms had conducted wind and solar R\&D in the 1970s and 1980s, yet lack of market demand eventually prompted most to shut their renewable energy divisions. ${ }^{49}$ The majority of new firms entering U.S. wind and solar sectors in the late 1990s and early 2000s were startups seeking to lower the cost of renewable energy through technological breakthroughs. Patent counts reflect this focus on invention: U.S. firms and research institutes account for approximately 25 percent of cumulative wind and solar energy patents until 2009, roughly twice the number of China or the European Union. ${ }^{50}$

In the solar sector, many of the new firms focused on the development of thin film technologies, which promised to lower prices by replacing silicon, an expensive raw material, with cheaper alternatives. Other firms were experimenting with new manufacturing processes and new types of solar technologies, including cells that could be printed on paper and plastic. ${ }^{51}$ By 2009, out of one hundred solar companies operating in the United States, at least seventy-three were startups. ${ }^{52}$

48 Earth Policy Institute (2015). For comparison, nuclear energy plants generally have an electric generation capacity of roughly 1,000 MW.

49 Colatat et al. (2009); Heymann (1995), 349-54.

50 Bettencourt et al. (2013), 3.

51 Morton (2006).

52 Knight (2011), 176. 
Table 3: Varieties of Innovation

\begin{tabular}{|c|c|c|c|}
\hline & United States & Germany & China \\
\hline Type of Innovation & Invention & Ancillary Innovation & $\begin{array}{l}\text { Innovative } \\
\quad \text { Manufacturing }\end{array}$ \\
\hline $\begin{array}{l}\text { Challenge } \\
\text { Addressed }\end{array}$ & $\begin{array}{l}\text { Development of } \\
\text { new technology }\end{array}$ & $\begin{array}{l}\text { Automation, production } \\
\text { equipment, complex } \\
\text { components }\end{array}$ & $\begin{array}{l}\text { Commercialization, } \\
\text { scale-up of new } \\
\text { technologies }\end{array}$ \\
\hline Firm Type & Startups & Suppliers & Manufacturers \\
\hline Predominant Firm Size & $>500$ Employees & $>2000$ Employees & $<2000$ Employees \\
\hline Production Scale & Low/None & Medium/Low & High \\
\hline
\end{tabular}

Although fewer in number, U.S. wind startups also attempted to decrease the cost of wind energy with radically different designs. To this end, Clipper Windpower proposed replacing a single turbine generator with several smaller generators to increase efficiency. ${ }^{53}$ Boulder Wind attempted to make obsolete gearboxes in turbine designs and Ogin borrowed principles from jet engines to develop alternatives to the traditional three-blade design (Table 4). ${ }^{54}$ Others, such as a startup called Vortex, tried to eliminate blades altogether. ${ }^{55}$

In Germany, large numbers of small and medium-sized suppliers from legacy industries diversified into renewable energy sectors by focusing on what I call ancillary innovation, the development of complex componentry and production equipment. Interview data reveal that the absence of specialized suppliers in renewable energy industries had previously required wind and solar firms to resort to improvisation, repurposing of production equipment from other industries, and the modification of components from other industrial products for application in wind turbines and solar PV modules. Germany's existing manufacturing firms possessed a rich fabric of capabilities applicable to the development of wind turbine components and production lines for the solar industry that could address these needs. German firms subsequently responded to this opportunity by applying their niche capabilities to global renewable energy sectors. Firms entered from a variety of existing industries, including machine building, automation and laser processing equipment, metal fabrication, and shipbuilding. ${ }^{56}$

53 Goudarzi and Zhu (2013), 199.

54 Boulder Wind Power (1999); Gertner (2013).

55 McKenna (2015).

56 Author interviews: CTO, German solar PV manufacturer, May 17, 2011; head of German operations, global equipment manufacturer, May 18, 2011; CEO, German equipment manufacturer, May 10, 2011; CTO, German solar PV manufacturer, May 23, 2011; plant manager of German 
Table 4: R\&D Activities, Select Wind and Solar Firms

\begin{tabular}{|c|c|c|}
\hline Firm & Background & R\&D Focus \\
\hline \multicolumn{3}{|r|}{ ( } \\
\hline Innovalight (Solar) & $\begin{array}{l}\text { Silicon Valley startup, } \\
\text { founded } 2003\end{array}$ & $\begin{array}{l}\text { - R\&D on silicon ink nanomaterial to increase cell efficiency, funded by DOE and NREL. } \\
\text { Research with JA Solar (China), acquired by DuPont (2011). }\end{array}$ \\
\hline MiaSolé (Solar) & $\begin{array}{l}\text { Silicon Valley startup, } \\
\text { founded } 2004\end{array}$ & $\begin{array}{l}\text { - VC-funded ( } \$ 550 \text { Million) development of flexible thin-film cell on stainless steel } \\
\text { substrate; experimental production line; acquired by Hanergy, China (2012). }\end{array}$ \\
\hline Ogin (Wind) & $\begin{array}{l}\text { Aerospace spin-off, } \\
\text { founded } 2008\end{array}$ & $\begin{array}{l}\text { - VC and ARPA-E funding to develop jet-engine based high-efficiency wind turbines; some } \\
\text { R\&D and component development in China. }\end{array}$ \\
\hline Makani (Wind) & $\begin{array}{l}\text { California-based startup, } \\
\text { founded } 2006\end{array}$ & $\begin{array}{l}\text { - Google-backed R\&D on kite-based flying wind turbines to increase generation efficiency; } \\
\text { acquired by Google X in } 2013 \text { while still prototyping. }\end{array}$ \\
\hline \multicolumn{3}{|r|}{ 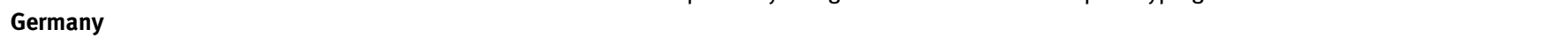 } \\
\hline Schmid Group (Solar) & $\begin{array}{l}\text { Family-owned. Founded as } \\
\text { foundry in } 1864\end{array}$ & $\begin{array}{l}\text { - Background in circuit board printers, develops turnkey solar production lines (2001); R\&D } \\
\text { on selective emitter cell lines with Chinese partner (2009). }\end{array}$ \\
\hline RENA (Solar) & Private, founded in 1993 & $\begin{array}{l}\text { - Applies R\&D on semiconductor equipment to wet bench chemical processing equipment } \\
\text { for solar; currently work on passivated emitter and PERC cells. }\end{array}$ \\
\hline Eickhoff (Wind) & $\begin{array}{l}\text { Founded } 1864 \text {, equipment } \\
\text { for mining sector }\end{array}$ & $\begin{array}{l}\text { - Uses in-house foundry and background in gearboxes for mining to develop wind turbine } \\
\text { gearboxes; small-batch production of ultra-large, offshore gearboxes. }\end{array}$ \\
\hline VEM Sachsenw. (Wind) & $\begin{array}{l}\text { Family-owned machine } \\
\text { builder, founded } 1903\end{array}$ & $\begin{array}{l}\text { - Background in generators, engines for streetcars; R\&D on wind turbine generators } \\
\text { beginning in 1998; small-batch production of ultra-large, off-shore generators. }\end{array}$ \\
\hline \multicolumn{3}{|r|}{ ( S } \\
\hline JA Solar (Solar) & $\begin{array}{l}\text { NASDAQ-listed PV } \\
\text { producer, founded } 2005\end{array}$ & $\begin{array}{l}\text { - Founded by returning overseas Chinese scientists, focus on commercialization of high } \\
\text { efficiency multi-SI cells; first to apply silicon ink technology (with Innovalight). }\end{array}$ \\
\hline CSUN (Solar) & $\begin{array}{l}\text { NASDAQ-listed PV } \\
\text { producer, founded } 2004\end{array}$ & $\begin{array}{l}\text { - Founded by returning overseas Chinese scientists, focus on commercialization of high } \\
\text { efficiency mono and poly-SI cells; first to commercialize selective emitter cells. }\end{array}$ \\
\hline Goldwind (Wind) & $\begin{array}{l}1998 \text { Spin-off from state- } \\
\text { owned firm }\end{array}$ & $\begin{array}{l}\text { - R\&D on commercialization of gearless wind turbines to avoid maintenance associated } \\
\text { with traditional gearbox designs; in collaboration with Vensys (Germany). }\end{array}$ \\
\hline Mingyang (Wind) & $\begin{array}{l}2006 \text { spin-off from } \\
\text { electrical equipment } \\
\text { firm }\end{array}$ & $\begin{array}{l}\text { - R\&D on commercialization of super compact drive turbines to lower maintenance cost, } \\
\text { especially offshore; in collaboration with Aerodyn (Germany). }\end{array}$ \\
\hline
\end{tabular}

Source: Information compiled from company websites and public financial filings. 
By 2011, VDMA, the German Engineering Federation, listed more than 170 member firms active in the wind industry, only ten of which were manufacturers of wind turbines. The vast majority of firms developed towers, blades, mechanical components, hydraulics systems, and production equipment for the wind industry. ${ }^{57}$ Similarly, in the PV sector, more than seventy firms offered production lines, automation equipment, coatings, and laser processing machines. With roughly 41,000 employees in 2010, employment in solar PV equipment and component firms far surpassed the 12,000 jobs in Germany's solar module manufacturers in the same year. ${ }^{58}$ Of the four vertically-integrated solar manufacturers operating in Germany in 2011, only two remained in existence by 2014. Their combined annual production capacity of below two megawatt amounted to less than a single Chinese PV manufacturing plant. ${ }^{59}$ The small number of domestic wind turbine and solar PV manufacturers made Germany's renewable energy suppliers highly dependent on global markets. Export quotas of more than 50 percent in the solar sector and up to $\mathbf{8 0}$ percent in the wind industry underline the tight integration of Germany's wind and solar firms into global renewable energy supply chains. ${ }^{60}$

Chinese wind and solar firms, by contrast, focused on technical capabilities in commercialization and scale up-which I call skills in innovative manufacturingthat neither U.S. startups nor German suppliers had established in-house. The majority of wind turbine producers spun-off from state-owned or formerly stateowned manufacturing firms. In the solar industry, firms were frequently founded by Chinese scientists educated in solar PV research laboratories abroad. ${ }^{61}$ In the late 1990s and early 2000s, when these firms entered wind and solar sectors, few manufacturers of wind turbines and solar panels were producing at scale. While technology could be accessed in global networks, mass-manufacturing knowledge was not available. According to Wu Gang, the founder of Goldwind, one of China's first wind turbine firms: "Whole blades dropped off. The main shafts broke. It was really very dangerous." ${ }^{2}$ Chinese firms subsequently focused their efforts on building innovative capabilities and engineering knowledge around the commercialization and rapid scale-up of complex wind and solar technologies.

gearbox manufacturer, May 16, 2011; plant manager of German generator manufacturer, May 17, 2011.

57 Germany Trade \& Invest (2010); Arbeitsgemeinschaft Windenergie-Zulieferindustrie (2012).

58 Germany Trade \& Invest (2011b, 2011c).

59 Germany Trade \& Invest (2011a, 2014).

60 Fischedick and Bechberger (2009), 26.

61 See Alexander (2013).

62 Osnos (2009), 55. 
By 2012, China's renewable energy firms accounted for over 60 percent of the global production of solar PV modules and nearly half of the world's wind turbines. ${ }^{63}$ Seven of the ten largest solar manufacturers and four of the ten largest wind turbine producers in the world were Chinese firms. ${ }^{64}$ The majority of these producers continued to license technology and source components and production equipment abroad. ${ }^{65}$ Site visits instead revealed designated R\&D teams with advanced capabilities in rapidly translating complex technologies into mass-manufacturable products. Such tasks required improvements to process designs long associated with manufacturing innovation, but also entailed changes to product designs to accommodate manufacturing requirements, to incorporate new materials and components, and to meet cost targets for final products. ${ }^{66}$

Engineering teams specialized in innovative manufacturing were frequently organized in a separate $R \& D$ division solely focused on the challenge of scale-up and mass production. At the wind turbine manufacturer Ming Yang, for instance, out of $300 \mathrm{R} \& \mathrm{D}$ staff in 2010, about one third focused on the development of new technologies, while the remaining engineers worked on bringing existing technologies to mass production. ${ }^{67}$ Similarly, Trina Solar reported that out of 425 employees working in its R\&D division in 2012, seventy-nine focused on technology development and the remaining 346 engineers devised solutions to the challenges of commercialization in a designated test facility with production lines solely dedicated to R\&D. ${ }^{68}$ Even as the wage gap between urban workers in coastal and interior provinces increased rapidly, wind and solar firms maintained knowledgeintensive innovative manufacturing strategies in high-wage coastal locations. ${ }^{69}$ Chinese solar PV manufacturers were among the first firms to employ fully automated production lines in response to changes in the domestic labor market. ${ }^{70}$

63 Earth Policy Institute (2015).

64 Bebon (2013); IHS Solar (2013).

65 Lewis (2013), 136-37.

66 Author interviews: Senior VP global supply chains, Chinese solar manufacturer, March 13, 2011; CTO and director of R\&D at Chinese solar manufacturer, August 26, 2011; head of China operations, European wind turbine engineering firm, January 13, 2011; CEO, European wind turbine engineering firm, May 20, 2011; CTO, Chinese wind turbine manufacturer, August 29, 2011; CEO, Chinese solar cell manufacturer, August 10, 2011; president, Chinese wafer manufacturer, August 26, 2011. CEO, Chinese cell and module manufacturer, interviewed June 28, 2013. Nahm and Steinfeld (2014).

67 China Ming Yang Wind Power Group Limited (2011), 54.

68 Trina Solar (2012), 64-65.

69 Li et al. (2012), 62.

70 Author interviews: CTO and director of R\&D at Chinese solar manufacturer, August 26, 2011; CEO, Chinese cell and module manufacturer, interviewed June 28, 2013. See also Nahm and Steinfeld (2014). 
Although wind and solar sectors in China, Germany, and the United States developed rapidly and simultaneously throughout the early 2000s, the majority of firms in each location did not compete directly. As is illustrated in Table 4, firms established distinct-and often complementary-technological capabilities to carve out unique competitive niches in global renewable energy sectors.

\subsection{Building on Industrial Legacies}

In responding to renewable energy policies in China, Germany, and the United States, firms replicated distinct national patterns of industrial specialization. Industries established before the development of wind and solar sectors defined which, if any, existing firms were able to diversify into renewable energy industries and which institutions and policies were available to support innovation in the broader economy. Renewable energy firms did not abandon such institutions in the course of entering emerging global industries. Rather, firms applied them to wind and solar sectors, thereby joining political coalitions in support of legacy institutions.

In the United States, wind and solar sectors evolved in the context of a declining U.S. manufacturing industry. The number of manufacturing plants employing more than one thousand workers dropped by half between 1977 and $2007 .{ }^{71}$ Losses were particularly strong in sectors such as aerospace, semiconductors, machine tools, and automotive components, the industries with the most technical overlap with renewable energy sectors. ${ }^{72}$ Between 1998 and 2010, nearly 1,200 plants closed in the semiconductor industry, a decline of 40 percent. In the machine tool industry, foreign penetration of the U.S. market rose from 30 percent in 1983 to 72 percent in 2008, with sub-sectors, such as metal forming, reaching import rates of 91 percent. ${ }^{73}$

Interviews with wind and solar CEOs indicate that rather than rebuilding manufacturing capabilities that had already vanished, the vast majority of US renewable energy firms chose instead to utilize institutions for research and development in responding to industrial policies for renewable energy sectors. ${ }^{74}$ First, American wind and solar firms relied on a national R\&D infrastructure that encouraged universities to make new technologies developed with support

71 Holmes (2011), 6.

72 Pisano and Shih (2012), 6-8.

73 Yudken (2010), 6-12.

74 Author Interviews: CEO of metal forming manufacturer, October 24, 2012; CEO of aerospace supplier, April 27, 2012; CEO of steel manufacturing firm, October 24, 2012; CEO of Silicon Valley solar startup, August 24, 2011. 
from federal research grants available to the private sector. As part of a series of legislative changes that eased the flow of technologies from universities to firms, the Bayh-Dole Act of 1980 permitted universities and research institutes to patent discoveries that resulted from federally funded research and to offer exclusive licenses to third parties. ${ }^{75}$ By 1993, many universities and research institutes had established designated technology transfer and licensing offices and jointly held more than 4000 active license agreements with firms. ${ }^{76}$

Once startups had moved technologies from university research facilities into the private sector, firms frequently relied on federal $R \& D$ support to fund operations. Federal R\&D grants constituted a critical source of capital in the absence of market demand for expensive early-stage technologies. As part of the so-called PVMaT program, for instance, the Department of Energy invested USD 289 million in R\&D for new solar technologies between 1991 and 2008. For a wide range of solar firms, including Evergreen and Solarex, such funding was the sole source of revenue in the years until their technologies matured. ${ }^{77}$ In the wind sector, too, federal funds remained critical for firms whose early-stage technologies were not yet ready for commercialization. Among other firms, Clipper, AML, and Boulder Wind Power drew grants and technical assistance from NREL and the Department of Energy. ${ }^{78}$ NREL supported Clipper in the development of a turbine for low wind speeds, for instance, covering half of the USD 19 million in $R \& D$ expenses to develop a prototype between 2002 and $2006 .{ }^{79}$

Second, American wind and solar firms took advantage of a large venture capital (VC) industry, increasingly willing to invest in renewable energy startups under the prospect of growing market demand. Global venture capital investment in clean energy technologies multiplied from USD 200 million in 2000 to USD 2.5 billion by 2007; U.S.-based VCs investing in U.S. startups accounted for 82 percent of overall VC investment in renewable energy. ${ }^{80}$ In 2011, U.S. venture capital firms invested USD 11 billion in American clean technology businesses, compared to USD 9 billion invested by non-U.S. venture capital firms outside of the United States. Although venture capital funds played a critical role in allowing startup firms to test and improve their early-stage products once they had left universities and research institutes, the basic technologies of most startup firms sprung from federally funded research. VCs were neither willing to invest in such high-risk early

75 Mowery et al. (2004).

76 Henderson et al. (1998), 120-21.

77 O'Connor et al. (2010), 3-11.

78 NREL (2002).

79 Department of Energy (2006).

80 Jennings et al. (2008), 9. 
stage $R \& D$, nor in the capital-intensive manufacturing facilities required for scaleup and mass production. ${ }^{81}$

Wind and solar startups identified these existing institutional resources and utilized them to replicate a pattern of industrial specialization structured around capabilities in the invention of new technologies. Large multinational firms, including GE and Applied Materials, a supplier of production equipment, entered renewable energy sectors through the acquisition of such startups. Less prevalent in the U.S. context were firms focused on commercialization and small- and medium-sized component suppliers, which were unable to benefit from the national R\&D infrastructure focused on invention. Many faced difficulty in funding manufacturing facilities and long-term R\&D projects required to enter wind and solar sectors. ${ }^{82}$

In Germany, by contrast, renewable energy policy mobilized small- and medium-sized firms (SMEs) from legacy sectors of the German economy to diversify into new industries. In 1995, just prior to the development of global renewable energy markets, the production of machinery and equipment made up 28 percent of manufacturing activity. Overall, 6.3 percent of value added in Germany came from machinery and equipment manufacturing firms, compared to 3.5 percent in the Untied States. ${ }^{83}$ Small firms played a significant role in these sectors. In 2002, for instance, SMEs made up 98.2 percent of businesses and 38.2 percent of revenue in machinery and equipment manufacturing. ${ }^{84}$ Although many existing manufacturing firms possessed the type of manufacturing experience and knowledge required for the production of complex machines and components, applying existing skills to emerging wind and solar industries necessitated extensive firmlevel learning. Entry into renewable energy industries entailed the modification and augmentation of existing capabilities and technologies. In interviews, firms reported development times of two to four years and R\&D budgets of several million Euro, making it a challenging endeavor for smaller firms. ${ }^{85}$

In the process of developing wind and solar technologies, German suppliers utilized three sets of legacy institutions, relying precisely on the types of arrangements that literatures have deemed most vulnerable to changes in the international economy. First, German wind and solar suppliers built on a long tradition

81 Mazzucato (2013), 127-29.

82 Spada (2010). Author interviews: CEO, U.S wind turbine startup, July 6, 2011; head of China operations, U.S. solar startup, August 26, 2011.

83 Author calculations based on OECD STAN database, 2013.

84 Günterberg and Kayser (2004), 8.

85 Author interviews; CEO, German equipment manufacturer, May 10, 2011; CTO, German solar PV manufacturer, May 23, 2011; plant manager of German gearbox manufacturer, May 16, 2011; plant manager of German generator manufacturer, May 17, 2011. 
of collaborating with other firms to solve complex technical challenges that could not be mastered in-house. To level the playing field for SMEs, the federal government since the 1950s offered R\&D funding for Industrial Collaborative Research (ICR- Industrielle Gemeinschaftsforschung) - research projects that involved partnerships between several firms and research institutes. ${ }^{86}$ Industry contributions allowed relatively modest sums of federal government support-in 2008, Euro 123 million (USD 135 million) in federal subsidies were spent on ICR funding, and a total of Euro 2.6 billion (USD 2.9 billion) have been dispensed since the inception of ICR programs in 1954-to initiate much larger R\&D efforts. ${ }^{87}$ Estimates suggest that as little as 15 percent of funds spent on ICR projects came from government coffers. ${ }^{88}$

In interviews, wind and solar suppliers reported relying on ICR programs to access technological capabilities they could not establish in-house. The director of a research collaboration among machinery and equipment firms described how small suppliers joined forces on the development of new alloys that none of the partners could have developed alone. ${ }^{89}$ Other firms used ICR networks to fund joint development work with research institutes or used contacts from past projects to independently facilitate collaboration with external research centers. The CEO of a manufacturer for production equipment for solar modules recalled using such ties to establish an R\&D project with the Fraunhofer Institute for Solar Energy Systems (ISE) in Freiburg. ${ }^{90}$ In a survey of sixty firms in the solar PV industry, 72 percent of firms that had received public support for collaborative research stated that they would not have participated in the absence of government subsidies. Seventy-four percent of all respondents had partaken in collaborative $R \& D$ efforts. ${ }^{91}$

Second, firms relied on relationships with local credit unions (Sparkassen), which were willing to provide loans for long-term development projects after demand-side subsidies had created stable market conditions for renewable energy. Local credit unions were familiar with firms' R\&D practices and willing to finance diversification into new sectors. Firms reported either supplementing such loans with retained earnings or completely relying on internal funds for R\&D. Among the firms interviewed for this project, the CEO of only one firm

86 Rothgang et al. (2011).

87 Eckl and Engel (2009), 296-98.

88 Rheinisch-Westfälisches Institut für Wirtschaftsforschung and WSF Wirtschafts- und Sozialforschung Kerpen (2010), 399.

89 Author interview, director of research association, May 25, 2012.

90 Author interview, CEO, solar module equipment manufacturer, May 10, 2011.

91 Seemann (2012), 355-59. 
indicated floating a bond in order to finance the construction of a new production facility, adding that "financing has never been an issue for us."92 The high share of family-controlled firms among German SMEs further facilitated entry into wind and solar sectors through complex, long-term R\&D projects. Planning horizons in family businesses created a willingness to forgo short-term profits in favor of future returns. Not subject to shareholders' focus on quarterly earnings, they were able to cross-subsidize $R \& D$ from activities in other sectors and use retained earnings for wind and solar research. ${ }^{93}$ Although loans and retained earnings provided relatively modest sums for $R \& D$ projects when compared to venture capital financing available to high-technology firms in the United States, these funds had few constraints attached to them.

Third, the recruitment of highly-skilled production workers and their continuous training were essential in product development processes. Production staff often identified problems, suggested appropriate technical solutions, and implemented these solutions together with $R \& D$ engineers. According to the Director of $R \& D$ for a solar equipment supplier, all production staff had gone through industry-specific training in Germany's vocational training system, but engineers had in most cases also completed an apprenticeship before entering university. Despite rigorous training for production workers and R\&D engineers, tacit knowledge acquired on the job was critical. "Computer assisted design [CAD] software is unable to simulate the conditions that we find in our machines. So what we do instead is to build the machine, then test it, tweak the parameters, and then test it again. A lot of this process requires tacit knowledge. Our capital is the experience of our staff. They didn't gain this [experience] in university, they learned it on the job."94

To find, train, and retain skilled workers, firms participated in existing labor market institutions. Industry associations maintained programs for highly industry-specific vocational training in the form of apprenticeships and, increasingly, dual degree programs (duales Studium) offering joint practical training and a university education at vocational universities (Berufsakademie). Strong worker representation and employment protection legislation slowed employment turnover, even as a series of labor market reforms allowed for more flexible employment contracts. ${ }^{95}$ Barred from organizational restructuring through large-scale hiring and firing, German manufacturers instead invested in their existing workforce to

92 Author interviews: CEO of solar equipment manufacturer, May 20, 2011; plant manager, generator supply firm, May 17, 2011.

93 Berger (2013), chapter 5.

94 Author interview, head of R\&D, solar PV equipment manufacturer, May 11, 2011.

95 OECD (2012), 43. 
meet the skill requirements of new $R \& D$ and production activities. To retain experienced production staff during recessions and seasonal downturns, wind and solar equipment suppliers made use of federal short-time labor policies (Kurzarbeit), which offer government subsidies for wages during downturns. ${ }^{96}$

In China, wind and solar firms incrementally built on capabilities in mass production to develop skills in innovative manufacturing. Over the course of the 1990s, manufacturing firms from Taiwan and Hong Kong moved labor-intensive export production to low-cost manufacturing locations in China's coastal development zones. Between 1985 and 2005, 60 percent of FDI arriving in China originated in Hong Kong, Taiwan, and Macau. Eighty-eight percent of high-technology exports during the 1990s were manufactured by foreign-invested enterprises. ${ }^{97}$ Foreign-invested firms provided training opportunities for staff in economic development zones, encouraged local governments to provide incentives for mass manufacturing in China, and attracted large supplier industries for materials, export logistics, and other complementary capabilities required for large-scale manufacturing.

In this context, China's newly established wind and solar manufacturers participated in government $R \& D$ programs intended to support the development of indigenous $R \& D$ capabilities, yet interview evidence reveals that many firms repurposed such funds to incrementally build on existing manufacturing skills. ${ }^{98}$ For instance, Goldwind, one of China's largest wind turbine manufacturers, received central government funding for almost every generation of wind turbine it developed. Under the 9th and 10th Five Year Plans, Goldwind participated in national science and technology programs for $R \& D$ and the commercialization of $600 \mathrm{~kW}$, $750 \mathrm{~kW}$, and $1 \mathrm{MW}$-scale turbine systems. It also received support from the provincial-level Department of Science and Technology for R\&D related to 1.5 MW, 2.5 MW, and 3 MW turbines. Yet Goldwind used government R\&D support not to establish capabilities in the invention of new technologies, but instead focused on improving its engineering capabilities in adjusting, improving, and preparing turbine designs for mass production in collaboration with the German firm Vensys (see also Table 5). ${ }^{99}$

96 Eichhorst and Marx (2009); OECD (2012), 47.

97 Naughton (2007), 417.

98 Author interviews, China, 2009-2012. In particular: senior VP global supply chains, Chinese solar manufacturer, March 13, 2011; CTO and director of R\&D at Chinese solar manufacturer, both August 26, 2011; head of China operations, European wind turbine engineering firm, January 13, 2011; CEO, European wind turbine engineering firm, May 20, 2011; CTO, Chinese wind turbine manufacturer, August 29, 2011; CEO, Chinese solar cell manufacturer, August 10, 2011; president, Chinese wafer manufacturer, August 26, 2011. CEO, Chinese cell and module manufacturer, June 28, 2013. See also Nahm and Steinfeld (2014).

99 CRESP (2005), 27-30; Tan and Seligsohn (2010). 
Table 5: Collaborative Product Development at Goldwind, China

\begin{tabular}{lll}
\hline Year & Technology & Foreign Partner \\
\hline $\mathbf{1 9 9 8}$ & 600kW Turbine & Jacobs Energie (Germany), license \\
$\mathbf{2 0 0 1}$ & $1.2 \mathrm{MW}$ direct-drive turbine & Vensys (Germany), license \\
$\mathbf{2 0 0 5}$ & $1.5 \mathrm{MW}$ direct-drive turbine & Vensys (Germany), license \\
$\mathbf{2 0 1 0}$ & $2.5 \mathrm{MW} / 5 \mathrm{MW}$ direct drive turbines & Vensys (Germany), joint development \\
Ongoing & $10 \mathrm{MW}$ offshore turbine & Vensys (Germany), joint development \\
\hline
\end{tabular}

Source: CRESP 2005, 27-30; Tan and Seligsohn 2010. Additional information compiled from company websites.

Solar manufacturers similarly took advantage of central government R\&D programs. LDK Solar, for instance, participated in a national project under the 863 Program to develop environmentally friendly solar PV production processes and took part in two Torch Program initiatives to improve solar wafers and develop new technologies to reduce industrial waste in wafer cutting. ${ }^{100}$ When central-government policy allowed the establishment of state key laboratories in enterprises in 2007, two solar firms, Trina Solar and Yingli, were among the first that were awarded such nationally-accredited and centrally-funded research laboratories on site. ${ }^{101}$ However, R\&D divisions established with the support of central government programs focused on the engineering and design challenges in the commercialization of new technologies, rather than the invention of such technologies itself. ${ }^{102}$

Even as China's wind and solar firms engaged in knowledge-intensive activities, they relied on institutions supporting the traditional manufacturing economy. Government support for newly established wind and solar firms included land deals and tax breaks common across China's economic development zones. For firms setting up production facilities, local governments offered access to financing, channeling bank loans and other forms of funding to local firms. Local governments were critical brokers in such deals and loans were frequently guaranteed by municipal government entities. The China Development Bank alone, one of three state-owned policy banks charged with raising funds for infrastructure and development projects, extended USD 29 billion in credit to the fifteen largest wind and solar firms. ${ }^{103}$ Not only was local government support critical in securing such

100 LDK Solar (2014).

101 Trina Solar (2013b); Yingli Green Energy Holding Company Limited (2010).

102 Nahm and Steinfeld (2014). Author interview, R\&D engineer, Chinese solar PV manufacturer, March 27, 2015.

103 Bakewell (16 November 2011). 
loans, but local government guarantees allowed firms to obtain waivers on loan conditions usually attached to large investments in high-risk industries. ${ }^{104}$ The city of Wuxi, for instance, arranged a series of bank loans for Suntech, one of China's largest manufacturers of solar panels. ${ }^{105}$ In 2007, Yingli borrowed USD 18 million from the Bank of China backed by a local state-owned firm. ${ }^{106}$ In 2009, Trina secured a five-year credit line of USD 303 million from a syndicate of banks to expand its manufacturing capacity. ${ }^{107}$

Access to large-scale financing of course provided no guarantee for upgrading. Localities at times lent indiscriminately and contributed to overcapacity in global renewable energy markets. Yet local financing made possible the physical infrastructure on which innovative skills in commercialization and scale-up could be applied. In interviews, foreign partners of solar firms praised the R\&D conditions in Chinese manufacturing facilities, where access to capital allowed firms to dedicate entire production lines to testing and experimentation of new technologies under production conditions. ${ }^{108}$

To support local enterprises, municipalities also attracted suppliers of raw materials and manufacturing firms from related industries. Wuxi courted glass manufacturers and firms supplying silicone required for PV production. ${ }^{109}$ Baoding, where Yingli was located, branded itself as a 'green city' to attract a wide range of renewable energy firms and suppliers with complementary capabilities to local industrial parks. ${ }^{110}$ In other cases, wind and solar firms chose hightech development zones specifically for their existing industrial base. A history of shipbuilding and the presence of related supplier industries, including bearings manufacturing, persuaded Sinovel to open its first wind turbine manufacturing facility in Dalian. ${ }^{111}$ In Changzhou, where Trina and EGing Solar were producing cells and solar PV modules, the municipal government counted 109 firms manufacturing products and components for power generation equipment. ${ }^{112}$ For domestic manufacturers seeking to upgrade their capabilities in innovative

104 Trina Solar (2013a, F35-36).

105 Wuxi historical annals editorial office (2006), 293.

106 Yingli Green Energy Holding Company Limited (2008), F-28.

107 Trina Solar (2010), F-30.

108 Author interviews: CEO, Chinese solar manufacturer, August 20, 2011; CTO and director of R\&D at Chinese solar manufacturer, August 26, 2011; CEO, German equipment manufacturer, May 10, 2011; CTO, German equipment manufacturer, May 11, 2011.

109 Wuxi historical annals editorial office (2003), 219; Wuxi historical annals editorial office (2006), 292.

110 Baoding yearbook editorial office (2004/2005), 155.

111 Dalian historical annals editorial office (2007), 130-39.

112 Changzhou yearbook editorial committee (2005), 173. 
manufacturing, these local manufacturing economies provided supplier networks that allowed the purchase of large quantities of raw materials at short notice and offered a range of partners focused on scale-up to mass production. ${ }^{113}$

Firms in China, Germany, and the United States responded to industrial policies for renewable energy industries by building on existing industrial capabilities and by using institutions established in support of legacy sectors. Rather than abandon such institutions when entering new economic sectors, firms repurposed and applied these institutions to emerging wind and solar industries. In doing so, they expanded the political coalitions to support such institutions beyond the industries that originally backed them.

\subsection{Collaboration and the Global Division of Labor}

The ability to maintain national specializations in different types of technological capabilities was predicated on access to complementary skills which firms did not establish in-house. In this context, continued U.S. strength in invention, Germany's specialization in complex components and production equipment, and China's focus on technological innovation related to commercialization and scale-up were interdependent and mutually reinforcing. Contrary to expectations that firms would seek to emulate one another's capabilities, collaboration in global firm networks allowed firms to strengthen these distinct industrial practices. While collaborative relationships allowed firms to jointly develop successive generations of renewable energy technologies, the basic division of labor among firms with specialized capabilities remained durable over time.

In the solar industry, small and medium-sized German manufacturers of production equipment neither had the financial support nor the technological capabilities to establish large solar PV manufacturing operations. Nevertheless, the ability to develop manufacturing equipment required access to engineering knowledge about mass production. The most important sources of such complementary skills for German equipment producers were Chinese manufacturers. Already in 2000, Centrotherm, a German manufacturer of solar production lines, began selling its products to Chinese customers. Others quickly followed. ${ }^{114}$ Between 2000 and 2007, the export quota for German PV equipment producers rose from 10 percent to 51 percent, most of it destined for Chinese factories. ${ }^{115}$

113 Author interviews: CTO and director of R\&D at Chinese solar manufacturer, August 26, 2011; CTO, Chinese wind turbine manufacturer, August 29, 2011; president, solar PV firm, August 24, 2011 .

114 Nussbaumer et al. (2007), 109.

115 EuPD Research data cited in Fischedick and Bechberger (2009), 26. 
In interviews, German equipment suppliers reported that the scale of production activities and access to large-scale financing for manufacturing plants afforded their Chinese partners the option of setting aside considerable resources to test new production equipment. Several Chinese firms constructed demonstration facilities with full test production lines-so-called "Golden Lines" - on which new technologies could be developed in collaboration with German equipment suppliers. ${ }^{116}$ An analysis of 178 Sino-German technology collaborations between 2010 and 2012 conducted by the German Ministry for Research and Technology revealed more than a dozen such interactions between German machine builders and Chinese renewable energy firms. ${ }^{117}$

More than mere customers, Chinese manufacturers became long-term partners in the development of production equipment for new solar PV technologies. In the process of bringing new solar technologies from lab to market, China's producers were willing to take considerable risks in the development and application of new production technologies and materials. Schmid and Centrotherm, two German equipment suppliers, experimented with the development of production equipment for selective emitter cells, but were unable to find German producers willing to partner on the commercialization of this new technology. Ultimately, it was Chinese cell manufacturers that in 2009 were willing to collaborate with German suppliers on developing production equipment for elective emitter cells, adjusting their own production processes to test and optimize the new equipment together with German engineers. ${ }^{118}$ Roth and Rau, another German equipment supplier, in 2010 entered a similar agreement with a Chinese solar manufacturer for the development of production equipment for a new thin-film technology. ${ }^{119}$ Although Chinese manufacturers sourced basic production equipment from domestic suppliers, production lines for the latest PV technologies continued to be developed in Sino-German collaborations. ${ }^{120}$

American solar startups with limited capabilities in commercialization or the development of automation technology similarly relied on global networks to access complementary skills. For instance, Innovalight, a U.S. startup, developed a nanomaterial with application in the solar industry with funding from the Department of Energy (DOE) and the National Renewable Energy Laboratory

116 Author interviews: CEO, Chinese solar manufacturer, August 10, 2011; CEO, Chinese solar manufacturer, August 26, 2011; chief engineer, Chinese solar manufacturer, March 31, 2015.

117 Grune and Heilmann (2012).

118 Neuhoff (2012), 156.

119 Roth and Rau (2010).

120 Author interviews: managing partner, German solar PV equipment manufacturer, May 10, 2011; head of R\&D, German solar PV equipment manufacturer, May 11, 2011; CEO of German solar equipment manufacturer, May 20, 2011. 
(NREL). Although Innovalight and its research partners in the United States were able to determine that the nanomaterial could increase cell efficiency by up to 50 percent, it was through collaboration with a Chinese partner, JA Solar, that Innovalight was able to commercialize its technology. Under a collaborative development agreement, engineers from JA Solar and Innovalight jointly adapted the technology for use in mass manufacturing and successfully incorporated the new material in existing production processes in JA Solar's manufacturing facilities in China. The production lines on which initial tests occurred were developed in collaboration with the German firm Roth \& Rau. ${ }^{121}$ JA Solar's focus on innovation related to scale-up and mass production ultimately enabled the commercialization of Innovalight's technology, which the startup was subsequently able to sell to a wide range of solar manufacturers in China. ${ }^{122}$

Chinese, German, and American wind energy firms similarly relied on collaboration to access the full range of skills required to bring new technologies to market. Among the thirty-one largest wind turbine manufacturers in China, sixteen entered license agreements with foreign firms, fourteen entered jointdevelopment contracts, six autonomously developed wind turbine technologies, and three were joint venture operations. Seven firms both had joint-development and licensing agreements with foreign firms. ${ }^{123}$ These relationships with supply firms, joint venture partners, and license grantors were not cases of one-directional technology transfers. Nor were they attempts to simply emulate the capabilities of firms in advanced economies. Through their focus on innovative manufacturingcapabilities located at the intersection of traditional R\&D and manufacturingengineering teams in Chinese wind firms re-designed foreign-developed technologies so that they could be manufactured cheaper, faster, and at greater scale. By replacing materials and through the reconfiguration of internal product architectures of wind turbines and specific components, Chinese turbine manufacturers improved on foreign-developed technologies and in many cases significantly changed product designs. ${ }^{124}$ As the example of China's Goldwind and Germany's Vensys illustrates, such collaborative firm learning focused on successive generations of wind turbine technologies without changing the basic division of labor between Chinese firms and foreign partners (Table 5).

For German suppliers with capabilities in the development of complex components and prototypes but with little experience in scale-up to mass production, Chinese turbine producers became important partners in the commercialization

121 Osborne (2009).

122 Nahm and Steinfeld (2014).

123 List compiled from Lewis (2013), 136-37; Wang (2010), 197-203.

124 Nahm and Steinfeld (2014). 
of new technologies. In 2009, for instance, a Chinese wind turbine producer acquired a ten-year exclusive license for the manufacturing of a groundbreaking wind turbine design from a German supplier without in-house mass production capabilities. Although the German firm developed the turbine design-a new turbine technology which offers greater reliability and versatility through new and lightweight components-the design for manufacturability occurred on the site of the Chinese manufacturer. Engineers employed by the Chinese firm made design changes to simplify tooling and assembly processes, and, in cooperation with other local firms, reduced costs by localizing sourcing and by introducing substitute materials. Additional design adjustments were then made during the commercialization process to accommodate requirements for mass production. ${ }^{125}$

For U.S. wind energy firms with capabilities in the invention of new technologies, global partners supplied both components and design-for-manufacturing expertise. Even General Electric (GE), which entered the wind industry during the late 1990s through the acquisition of several smaller wind turbine startups, relied on capabilities in external firms while retaining a focus on invention. GE gearboxes, for instance, were developed in collaboration with the German firm Eickhoff. According to GE's chief wind engineer, Vincent Schelling, GE has to "put the knowledge in the gearbox manufacturers' hands. It would be better if we designed the gearbox and they built it, but we don't have all the knowledge."126 Over time, as increasing global demand for wind turbines necessitated ever larger manufacturing runs, Chinese suppliers offered engineering capabilities focused not on technological improvement, but on changing product designs to accommodate lower-cost manufacturing processes. ${ }^{127}$ As early as 2006, GE began co-developing gearboxes with Nanjing-based NGC to take advantage of local expertise in mass production, while continuing to rely on its existing German suppliers for small batch production runs and prototyping during early commercialization. ${ }^{128}$ By 2008, more than half of NGC's products were exported and their gearboxes were used in a wide range of GE wind turbines in all of GE's global markets. ${ }^{129}$

Of course, not all firms entered such global relationships. In Germany, early solar PV manufacturers tried to compete with Chinese competitors head-on, frequently failing to match Chinese capabilities in scale-up and rapidly falling

125 Author interviews: CEO, European wind turbine engineering firm, May 20, 2011; CTO, Chinese wind turbine manufacturer, August 29, 2011.

126 de Vries (2013); Windpower Monthly (2005).

127 Author interviews: plant manager of German generator manufacturer, May 17, 2011; head of China operations, global wind turbine manufacturer, January 21, 2011; head of China operations, European turbine manufacturer, October 28, 2010.

128 Windpower Monthly (2006).

129 Windpower Monthly (2008). 
prices. ${ }^{130}$ Lacking the institutional infrastructure that supported mass manufacturing capabilities in China, German manufacturing firms failed to raise the necessary funds to expand production facilities and were unable to hire engineers with the same production experience. ${ }^{131}$ Small American suppliers often had difficulty diversifying into wind and solar sectors, as they were unable to find global partners for collaboration. Having historically relied on multinational firms for access to global markets, smaller U.S. firms had few institutional resources that could help establish collaborative relationships. ${ }^{132}$ In successful cases, however, the ability to utilize external capabilities through collaboration in global supply chains enabled Chinese, German, and American firms to enter wind and solar sectors with highly specialized capabilities and without establishing in-house the full range of skills required to bring new renewable technologies to market. It is because such complementary capabilities could be accessed externally that firms were able to build on local institutional legacies and maintain distinct upgrading trajectories over time.

\section{Conclusion}

This article has argued that cross-national patterns of industrial specialization continue to diverge, even in new sectors such as wind energy and solar PV. Although firms in China, Germany, and the United States have all participated in the development of new technologies in renewable energy industries, they have done so through the incremental improvement of existing strengths and by repurposing existing domestic resources and institutions for application in new industries.

In contrast to existing literatures, this research indicates that new possibilities for specialization in the global economy have enabled, not hindered, firms to craft these distinct paths for participation in wind and solar sectors. Opportunities to access complementary skills through global partners have relieved firms of having to master all the activities required to develop and to commercialize new technologies. This has opened the way for firms to renew and augment existing national industrial practices, instead of abandoning them in favor of global best practices. Such continued national diversity in the structures of production and firms' industrial capabilities did not result from the state protecting the domestic

130 See, for instance, McKillop (2013).

131 Author interview, CTO, Managing Director Asia, German solar manufacturer, December 23, 2010.

132 Author Interviews: CEO of metal forming manufacturer, October 24, 2012; CEO of aerospace supplier, April 27, 2012; CEO of steel manufacturing firm, October 24, 2012; CEO of Silicon Valley solar startup, August 24, 2011. 
economy from the competitive pressures of globalization or from sticky institutional legacies. Rather, the findings presented here suggest that divergence in industrial specialization followed from individual firm choices to compete through the augmentation of existing industrial strengths, actively applying legacy institutions and resources in new industries.

As emerging industries, wind and solar sectors offer insights into industrial specialization in sectors that developed after the rise of global firm networks. Patterns of industrial specialization are likely to look different in legacy industries, in which vertically-integrated incumbents and production structures established before the rise of global chains continue to affect the division of labor. Recent scholarship offers some indication, however, that similar patterns of specialization are also emerging in other sectors. Breznitz and Murphree, for instance, have argued that Chinese electronics firms have developed innovative capabilities focused on rapid commercialization, while leaving invention and the development of production equipment to firms in other parts of the world. ${ }^{133}$ Herrigel et al., in a study of German auto and machine tool firms and their relationships with Chinese manufacturers, have shown that in these sectors, too, distinct industrial capabilities have led to collaboration and multi-directional learning among German firms and Chinese partners. ${ }^{134}$ Such outcomes are consistent with the data presented here.

The case of contemporary wind and solar sectors raises two broader questions about future patterns of industrial specialization. The first concerns the possibility that the distinct trajectories of learning observed in each of these locations may begin to converge over time, as firms' collaboration in global networks allows producers in developing economies to acquire the R\&D capabilities of their foreign partners. Barely three decades old, wind and solar sectors are rapidly developing industries, and there is indeed the possibility that firms eventually begin to encroach on each other's competitive strategies. Two reasons suggest, however, that this is unlikely to be the case. First, as this article has argued, wind and solar firms have thus far followed distinct trajectories. They have done so in two industries characterized by tacit knowledge and global networks that are not hierarchically controlled by individual lead firms, characteristics GVC scholarship tends to associate with increased opportunities for emulation. ${ }^{135}$ As discussed above, more than a decade after China's Goldwind first began to collaborate with the German firm Vensys, the division of labor between the two firms remains intact, even as the types of technologies they jointly develop has

133 Breznitz and Murphree (2011).

134 Herrigel et al. (2013).

135 Gereffi (1994); Gereffi et al. (2005). 
changed over time (Table 5). The second reason is simply that specialization is selfreinforcing. To break into the competitive niches of firms in other parts of the world now requires the development of ever more advanced technological capabilities without the support offered by the same type of domestic institutions.

The second question raised by this work concerns the economic viability of the different trajectories of specialization over time. Renewable energy firms in China, Germany, and the United States are differently exposed to the risks of two emerging industries that continue to be highly dependent on government support. German suppliers with diversified product portfolios are less vulnerable to the volatility of renewable energy markets than China's manufacturers, which have invested large sums in single-purpose production facilities. As manufacturing wages continue to rise in China, these firms will have to rely on their knowledge-intensive manufacturing skills to compete. While this will entail learning and augmentation of existing capabilities, the case of Germany suggests that such manufacturing-based competitive strategies can be sustained even in highwage, high-benefit locations. Differences across these different specializations also exist in terms of job creation and the ease of entering global networks. U.S. startups, for instance, create far fewer domestic jobs than their Chinese partners or German suppliers, fueling U.S. anxiety about the decline of the domestic manufacturing sector. Insertion into global firm networks is easier for highly networked German firms and Chinese manufacturers, whose large domestic market naturally attracts foreign partners, than for small U.S. startups without such support.

Ultimately, the evidence presented here suggests that the viability of each trajectory of specialization is now heavily dependent on the ability to access complementary capabilities in other parts of the world. While policy-makers may not be able to change the fundamental risks and rewards of each of these specializations, there is a role for the state in helping firms participate in global networks. The challenge may not be to preserve distinct national structures of production against the pressures of globalization and to prevent competition through trade barriers and import tariffs, but to ensure that sufficient numbers of domestic firms can apply their capabilities to new opportunities in global industries. Governments may be best advised to craft policies that allow for repurposing and firm experimentation without shutting off access to global partners in the hope that new activities will locate domestically.

\section{References}

Alexander, Cathy. 2013. Carbon Cutters. Available from http://www.crikey.com.au/thepowerindex/carbon-cutters/. (Accessed May 28, 2015). 
Arbeitsgemeinschaft Windenergie-Zulieferindustrie. 2012. Komponenten, Systeme Und Fertigungtechnik Für Die Windindustrie. Frankfurt: VDMA.

Bakewell, Sally. 2011. “Chinese Renewable Companies Slow to Tap \$47 Billion Credit.” Bloomberg. November 16.

Baldwin, Carliss, and Kim Clark. 2000. Design Rules. The Power of Modularity. Cambridge, MA: MIT Press.

Baoding yearbook editorial office. 2004/2005. Baoding Nianjian. Beijing: Fangzhi chubanshe.

Bebon, Joseph. 2013. “Top Wind Turbine Supplier in 2012: Vestas or GE.” North American Wind Power. March 26. http://nawindpower.com/top-wind-turbine-supplier-of-2012-vestas-or-ge/ (Accessed November 5, 2016).

Berger, Suzanne. 1996. "Introduction." In National Diversity and Global Capitalism, edited by Suzanne Berger and Ronald Dore. Ithaca, NY: Cornell University Press.

Berger, Suzanne. 2005. How We Compete. New York: Doubleday.

Berger, Suzanne. 2013. Making in America: From Innovation to Market. Cambridge, MA: MIT Press.

Berger, Suzanne, and Richard M. Locke. 2001. "Il Caso Italiano and Globalization." Daedalus 130 (3): 85-104.

Berger, Suzanne, and Michael J. Piore. 1980. Dualism and Discontinuity in Industrial Societies. Cambridge: Cambridge University Press.

Bettencourt, Luis M. A., Jessika E. Trancik, and Jasleen Kaur. 2013. "Determinants of the Pace of Global Innovation in Energy Technologies.” Plos ONE 8 (10).

Boulder Wind Power. 1999. Boulder Wind Power.http://www.boulderwindpower.com/. (Accessed March 29, 2014).

Breznitz, Dan. 2007. Innovation and the State: Political Choice and Strategies for Growth in Israel, Taiwan, and Ireland. New Haven, CT: Yale University Press.

Breznitz, Dan, and Michael Murphree. 2011. Run of the Red Queen: Government, Innovation, Globalization and Economic Growth in China. New Haven, CT: Yale University Press.

Bruns, Elke, Dörte Ohlhorst, Bernd Wenzel, and Johann Köppel. 2011. Renewable Energies in Germany's Electricity Market: A Biography of the Innovation Process. Heidelberg: Springer.

Bundesministerium für Wirtschaft und Technologie. 2011. Forschung FüR Eine Umweltschonende, ZuverlaäSsige Und Bezahlbare Energieversorgung -Das 6. Energieforschungsprogramm Der Bundesregierung. Berlin.

Chandler, Alfred D., and Takashi Hikino. 1997. "The Large Industrial Enterprise and the Dynamics of Modern Growth." In Big Business and the Wealth of Nations, edited by Alfred D Chandler, Franco Amatori, and Takashi Hikino. Cambridge: Cambridge University Press.

Changzhou yearbook editorial committee. 2005. Changzhou Nianjian. Changzhou: Changzhou difangzhi bangongshi.

China Ming Yang Wind Power Group Limited. 2011. Annual Report 2010, Form 20-F.

Colatat, Phech, Georgeta Vidican, and Richard K. Lester. 2009. "Innovation Systems in the Solar Photovoltaic Industry: The Role of Public Research Institutions.” IPC Working Paper Series. Cambridge, MA: MIT Industrial Performance Center.

CRESP. 2005. Zhongguo Fendian Chanyehua Fazhan Guojia Xingdong Fangan [National Action Plan for China's Wind Power Industry Development]. Beijing: Zhongguo Kezaisheng Nengyuan Guimohua Fazhan.

Dalian historical annals editorial office. 2007. Dalian Nianjian. Dalian: Dalian nianjian bianjibu.

Davis, Gerald F. 2009. Managed by the Markets: How Finance Reshaped America. Oxford: Oxford University Press. 
de Vries, Eize. 2013. “Close up - Own Foundries Give Strategic Edge.” Windpower Monthly (March).

Dedrick, Jason, and Kenneth L. Kraemer. 2011. "Value Capture in the Global Wind Energy Industry." Irvine, CA: Personal Computing Industry Center, UC Irvine.

Department of Energy. 2006. Wind Energy Program Portfolio. http://www.nrel.gov/docs/fy06osti/ 37937.pdf. (Accessed April 10, 2014).

Earth Policy Institute. 2015. Climate, Energy, and Transportation Data. http://www.earth-policy. org/data_center/C23. (Accessed August 1, 2016).

Eckl, Verena, and Dirk Engel. 2009. "Benefiting from Publicly Funded Pre-Competitive Research: Differences between Insiders and Outsiders." Ruhr economic papers. Essen: RheinischWestfälisches Institut für Wirtschaftsforschung.

Eichhorst, Werner, and Paul Marx. 2009. "Kurzarbeit - Sinnvoller Konjunkturpuffer Oder Verlängertes Arbeitslosengeld?” Wirtschaftsdienst 89 (5): 322-28.

Ernst, Dieter, and John Ravenhill. 1999. "Globalization, Convergence, and the Transformation of International Production Networks in Electronics in East Asia." Business and Politics 1 (1): 35-62.

Feenstra, Robert C. 1998. "Integration of Trade and Disintegration of Production in the Global Economy." The Journal of Economic Perspectives 12 (4): 31-50.

Fischedick, Manfred, and Mischa Bechberger. 2009. "Die Ökologische Industriepolitik Deutschlands Am Beispiel Der Solar- Und Windindustrie. Musterschüler Oder Problemkind?” Moderne Industriepolitik. Berlin: Friedrich-Ebert-Stiftung.

Gereffi, Gary. 1994. "The Organization of Buyer-Driven Commodity Chain: How Us Retailers Shape Overseas Production Networks." In Commodity Chains and Global Capitalism, edited by Gary Gereffi and Miguel Korzeniewicz. Westport, CT: Praeger.

Gereffi, Gary, John Humphrey, and Timothy Sturgeon. 2005. "The Governance of Global Value Chains." Review of International Political Economy 12 (1): 78-104.

Germany Trade \& Invest. 2010. Wind Energy Industry in Germany. Berlin.

Germany Trade \& Invest. 2011a. Leading Pv Manufacturers Produce in Germany. Berlin.

Germany Trade \& Invest. 2011b. Photovoltaic Equipment. Berlin.

Germany Trade \& Invest. 2011c. Photovoltaics-Made in Germany. Berlin.

Germany Trade \& Invest. 2014. Leading Pv Manufacturers in Germany. Berlin.

Gertner, Jon. 2013. "Flodesign's Jet-Engine Turbine Will Change the Way You Think About Wind Power." Fast Company Magazine (September).

Goudarzi, N., and W. D. Zhu. 2013. "A Review on the Development of Wind Turbine Generators across the World." International Journal of Dynamics and Control 1 (2): 192-202.

Grune, Susann, and Sebastian Heilmann. 2012. "Deutsch-Chinesische Technologiekooperation." China Analysis 99(December).

Günterberg, Brigitte, and Gunter Kayser. 2004. Sme's in Germany Germany Trade \& Invest. Facts and Figures 2004. Bonn: Institut für Mittelstandsforschung.

Hall, Peter A., and David Soskice. 2001. "An Introduction to Varieties of Capitalism." In Varieties of Capitalism: The Institutional Foundations of Comparative Advantage, edited by Peter A. Hall and David Soskice. Oxford: Oxford University Press.

Hall, Peter A., and Kathleen Thelen. 2009. "Institutional Change in Varieties of Capitalism." SocioEconomic Review 7 (1): 7-34.

Hassel, Anke. 2014. "The Paradox of Liberalization - Understanding Dualism and the Recovery of the German Political Economy." British Journal of Industrial Relations 52 (1): 57-81. 
Henderson, Rebecca, Adam B. Jaffe, and Manuel Trajtenberg. 1998. "Universities as a Source of Commercial Technology: A Detailed Analysis of University Patenting, 1965-1988.” Review of Economics and Statistics 80 (1): 119-27.

Herrigel, Gary, Volker Wittke, and Ulrich Voskamp. 2013. "The Process of Chinese Manufacturing Upgrading: Transitioning from Unilateral to Recursive Mutual Learning Relations." Global Strategy Journal 3 (1): 109-25.

Heymann, Matthias. 1995. Die Geschichte Der Windenergienutzung 1890-1990. Frankfurt: Campus.

Holmes, Thomas J. 2011. "The Case of the Disappearing Large-Employer Manufacturing Plants: Not Much of a Mystery after All." Minneapolis, MN: Federal Reserve Bank of Minneapolis.

Höpner, Martin, and Lothar Krempel. 2004. "The Politics of the German Company Network." Competition and Change 8 (4): 339-56.

Humphrey, John, and Hubert Schmitz. 2002. "Does Insertion in Global Value Chains Affect Upgrading in Industrial Clusters?” Regional Studies 36 (9): 1017-27.

Humphrey, John, and Hubert Schmitz. 2004. "Chain Governance and Upgrading: Taking Stock." In Local Enterprises in the Global Economy: Issues of Governance and Upgrading, edited by Hubert Schmitz. Cheltenham, UK: Edward Elgar.

IEA. 2013. Energy Technology R\&D Statistics. Paris.

IHS Solar. 2013. Integrated Pv Market Tracker - Q1 2013. Englewood CO: IHS.

Jennings, Charles E., Robert M. Margolis, and John E. Bartlett. 2008. A Historical Analysis of Investments in Solar Energy Technologies (2000-2007). Golden, CO: National Renewable Energy Laboratory.

Karplus, Valerie J. 2007. “Innovation in China's Energy Sector.” Stanford, CA: Stanford University Center for Environmental Science and Policy.

Keohane, Robert O., and Helen V. Milner. 1996. Internationalization and Domestic Politics, Cambridge Studies in Comparative Politics. Cambridge: Cambridge University Press.

Knight, Chris P. 2011. "Failure to Deploy: Solar Photovoltaic Policy in the United States." In The State of Innovation: The U.S. Government's Role in Technology Development, edited by Fred Block and Matthew Keller. London: Paradigm Publishers.

Laird, Frank, and Christoph Stefes. 2009. "The Diverging Paths of German and United States Policies for Renwable Energy: Sources of Difference." Energy Policy 37: 2619-29.

Lauber, Volkmar, and Lutz Mez. 2004. "Three Decades of Renewable Electricity Policies in Germany.” Energy \& Environment 15 (4): 599-623.

LDK Solar. 2014. R\&D Achievements.http://www.Idksolar.com/inn_rd.php (Accessed January 19, 2014).

Lee, Joonkoo. 2010. "Global Commodity Chains and Global Value Chains." In The International Studies Encyclopedia, edited by Robert A. Denmark. Oxford: Wiley-Blackwell.

Lewis, Johanna I. 2013. Green Innovation in China: China's Wind Power Industry and the Global Transition to a Low Carbon Economy. New York: Columbia University Press.

Lewis, Joanna I. 2014a. "Industrial Policy, Politics and Competition: Assessing the Post-Crisis Wind Power Industry." Business and Politics 16 (4): 511-47.

Lewis, Johanna I. 2014b. "The Rise of Renewable Energy Protectionism: Emerging Trade Conflicts and Implications for Low Carbon Development." Global Environmental Politics.

Li, Hongbin, Lei Li, Binzhen Wu, and Yanyan Xiong. 2012. "The End of Cheap Chinese Labor.” The Journal of Economic Perspectives 26 (4): 57-74.

Loferski, Joseph J. 1993. "The First Forty Years: A Brief History of the Modern Photovoltaic Age." Progress in Photovoltaics: Research and Applications 1 (1): 67-78. 
Mazzucato, Mariana. 2013. The Entrepreneurial State - Debunking Public Vs. Private Sector Myths. London: Anthem Press.

McKenna, Phil. 2015. “Bladeless Wind Turbines May Offer More Form Than Function.” Technology Review May 27.

McKillop, Andrew. 2013. "The Changing and Fading Dreams of German Energiewende." Energy \& Environment 24 (5): 785-92.

Morgan, Glenn, and Richard Whitley. 2012. Capitalisms and Capitalism in the Twenty-First Century. Oxford: Oxford University Press.

Morton, Oliver. 2006. "Solar Energy: A New Day Dawning?: Silicon Valley Sunrise.” Nature 443 (7107): 19-22.

Mowery, David C., Richard R. Nelson, Bhaven N. Sampat, and Arvids A. Ziedonis. 2004. Ivory Tower and Industrial Innovation: University-Industry Technology Transfer before and after the BayhDole Act. Stanford, CA: Stanford University Press.

Nahm, Jonas, and Edward S. Steinfeld. 2014. S“cale-up Nation: China’s Specialization in Innovative Manufacturing.” World Development 54: 288-300.

Naughton, Barry. 2007. The Chinese Economy - Transitions and Growth. Cambridge, MA: MIT Press.

Nemet, Gregory F. 2009. "Demand-Pull, Technology-Push, and Government-Led Incentives for NonIncremental Technical Change." Research Policy 38 (5): 700-09.

Neuhoff, Karsten. 2012. "The German Solar Industry.” In Meeting Global Challenges: German-U.S. Innovation Policy, edited by National Research Council. Washington, DC: National Academies Press.

NREL. 2002. "National Renewable Energy Laboratory - 25 Years of Research Excellence 19772002." Golden, CO: National Renewable Energy Laboratory.

Nussbaumer, Hartmut, Daniel Biro, Helge Haverkamp, and Karsten Bothe. 2007. "Forschung FüR Neue Technologien Und Ihre Wechselwirkung Mit Der Industrie.” Jahrestagung des Forschungsverbunds Sonnenenergie. Hannover.

O’Connor, Alan, Ross J. Loomis, and Fern M. Braun. 2010. "Retrospective Benefit- Cost Evaluation of Doe Investment in Photovoltaic Energy Systems.” Washington, DC: U.S. Department of Energy.

OECD. 2008. Oecd Reviews of Innovation Policy: China. Paris: OECD Publications.

OECD. 2012. Economic Surveys: Germany 2012. Paris: OECD Publishing.

Osborne, Mark. 2009. Ja Solar Working to Commercialize Innovalight's Silicon Ink Technology in 2010. http://www.pv-tech.org/news/ja_solar_working_to_commercialize_innovalights_silicon_ink_technology_in_20. (Accessed August 10, 2015).

Osnos, Evan. 21 December 2009. "Green Giant.” The New Yorker.

Pisano, Gary P., and Willy C. Shih. 2012. Producing Prosperity: Why America Needs a Manufacturing Renaissance. Boston, MA: Harvard Business Review Press.

Powell, Walter W. 2009. "The Capitalist Firm in the 21st Century: Emerging Patterns." In The Twenty-First-Century Firm: Changing Economic Organization in International Perspective, edited by Paul DiMaggio. Princeton, NJ: Princeton University Press.

REN21. 2012. Renewables 2012 Global Status Report. Paris: REN21 Secretariat.

REN21. 2015. Renewables 2015 Global Status Report. Paris: REN21 Secretariat.

Rheinisch-Westfälisches Institut für Wirtschaftsforschung, and WSF Wirtschafts- und Sozialforschung Kerpen. 2010. Erweiterte Erfolgskontrolle Beim Programm Zur Förderung Der Igf Im Zeitraum 2005-2009. Essen: Rheinisch-Westfälisches Institut für

Wirtschaftsforschung. 
Righter, Robert W. 1996. Wind Energy in America: A History. Norman, OK: University of Oklahoma Press.

Roth \& Rau. 2010. Roth \& Rau Ag Schließt Joint Venture Vertrag Mit Chinesischem Unternehmen. http://www.roth-rau.de/fileadmin/user_upload/shared/rr-website/Download/News/03-022010_ad-hoc.pdf. (Accessed March 29, 2015).

Rothgang, Michael, Matthias Peistrup, and Bernhard Lageman. 2011. "Industrial Collective Research Networks in Germany: Structure, Firm Involvement and Use of Results.” Industry and Innovation 18 (4): 393-414.

Ru, Peng, Qiang Zhi, Fang Zhang, Xiaotian Zhong, Jianqiang Li, and Jun Su. 2012. "Behind the Development of Technology: The Transition of Innovation Modes in China's Wind Turbine Manufacturing Industry." Energy Policy 43: 58-69.

Seemann, Mareike. 2012. Innovationsnetzwerke in Jungen Branchen - Formation, Morphologie Und Unternehmenstrategische Implikationen Am Beispiel Der Deutschen Photovoltaikbranche. Marburg: Metropolis-Verlag.

Shah, Vishal, and Jake Greenblatt. 2010. "Solar Energy Handbook." New York, NY: Barclays Capital.

Shrimali, Gireesh, Steffen Jenner, Felix Groba, Gabriel Chan, and Joe Indvik. 2012. "Have State Renewable Portfolio Standards Really Worked?” Berlin: German Institute for Economic Research.

Spada, Alfred. 2010. "U.S. Metalcasting for Wind Energy." Paper presented at the Wind Power Manufacturing \& Supply Chain Summit, Chicago, IL.

State Council. 2006. “Guojia Zhongchangqi Kexue He Jishu Fazhan Guihua Gangyao” [Mediumand Long-Term Strategic Plan for the Development of Science and Technology].

State Council. 2010. "Guowuyuan Guanyu Jiakuai Peiyu He Fazhan Zhanlüexing Xinxing Changye De Jueding" [Decision of the State Council on Accelerating the Fostering and Development of Strategic Emerging Industries]. State Council Document 2010/32.

Steinfeld, Edward S. 2004. "China's Shallow Integration: Networked Production and the New Challenges for Late Industrialization." World Development 32 (11): 1971-87.

Streeck, Wolfgang. 2009. Re-Forming Capitalism: Institutional Change in the German Political Economy. Oxford: Oxford University Press.

Streeck, Wolfgang, and Daniel Mertens. 2010. "Politik Im Defizit: Austerität Als Fiskalpolitisches Regime.” MPIfG Discussion Paper 10/5. Cologne: Max-Planck-Institut für Gesellschaftsforschung.

Streeck, Wolfgang, and Kathleen Ann Thelen. 2005. Beyond Continuity: Institutional Change in Advanced Political Economies. Oxford: Oxford University Press.

Sturgeon, Timothy. 2002. "Modular Production Networks: A New American Model of Industrial Organization." Industrial and Corporate Change 11 (3): 451-96.

Sturgeon, Timothy, Johannes Van Biesebroeck, and Gary Gereffi. 2008. "Value Chains, Networks and Clusters: Reframing the Global Automotive Industry." Journal of Economic Geography 8 (3): 297-321.

Tan, Xiaomei, and Deborah Seligsohn. 2010. "Scaling up Low-Carbon Technology Deployment: Lessons from China." Washington, DC: World Resources Institute.

Thelen, Kathleen. 2014. Varieties of Liberalization and the New Politics of Social Solidarity. Cambridge: Cambridge University Press.

Trina Solar. 2010. Annual Report 2009 - Form 20-F.

Trina Solar. 2012. Annual Report 2011 - Form 20-F.

Trina Solar. 2013a. Annual Report 2012 - Form 20-F. 
Trina Solar. 2013b. Trina Solar's State Key Laboratory of Pv Science and Technology Receives Ministry Accreditation. http://ir.trinasolar.com/phoenix.zhtml?c=206405\&p=irolnewsArticle\&ID=1874706\&highlight $=$. (Accessed January 19, 2014).

UNESCO. 2010. UNESCO Science Report 2010: The Current Status of Science Around the World. Paris, France: UNESCO Publishing, 389-390.

US-China Business Council. 2013. “China’s Strategic Emerging Industries: Policy, Implementation, Challenges, \& Recommendations." Washington, DC.

Wang, Zhengming. 2010. Zhongguo Fengdian Chanye De Yanhua Yu Fazhan [the Evolution and Development of China's Wind Power Industry]. Zhenjiang: Jiangsu Daxue Chubanshe.

Windpower Monthly. 2005. "A More Conservative Approach." Windpower Monthly November.

Windpower Monthly. 2006. "Gearbox Supply in Asia and Europe Expands - Wind Power Now an Industry Worth Making Investments For." October.

Windpower Monthly. 2008. "China Gearbox Factory Orders 5000 High Capacity Bearings.” September.

Wiser, Ryan, Mark Bolinger, and Galen Barbose. 2007. "Using the Federal Production Tax Credit to Build a Durable Market for Wind Power in the United States.” The Electricity Journal 20 (9): 77-88.

Wuxi historical annals editorial office. 2003. Wuxi Nianjian. Shanghai: Pudong dianzi chubanshe. Wuxi historical annals editorial office. 2006. Wuxi Nianjian. Beijing: Fangzhi chubanshe.

Yingli Green Energy Holding Company Limited. 2008. Annual Report for Fiscal Year Ending 12/31/ 2007 - Form 20-F.

Yingli Green Energy Holding Company Limited. 2010. State Key Laboratory of Pv Technology to Be Established at Yingli Green Energy's Manufacturing Base. http://ir.yinglisolar.com/phoenix. zhtml?c=213018\&p=irol-newsArticle\&ID=1375499\&highlight=. (Accessed January 19, 2014).

Yudken, Joel S. 2010. "Manufacturing Insecurity: America's Manufacturing Crisis and the Erosion of the U.S. Defense Industrial Base.” Washington, DC: Industrial Union Council, AFL-CIO.

Zhang, Sufang, Philip Andrews-Speed, and Meiyun Ji. 2014. "The Erratic Path of the Low-Carbon Transition in China: Evolution of Solar Pv Policy.” Energy Policy 67 (0): 903-12.

Zysman, John, and Mark Huberty. 2013. "Energy Systems Transformation for Sustainable Prosperity." In Can Green Sustain Growth?, edited by John Zysman and Mark Huberty. Stanford, CA: Stanford University Press. 